\title{
PENGARUH UKURAN BENANG DAN LEBAR MATA JARING TRAMMEL TERHADAP HASIL TANGKAPAN IKAN DEMERSAL
}

\author{
Wudianto*) dan Heri Harifin*)
}

\begin{abstract}
ABSTRAK
Penelitian pengaruh ukuran benang dan mata jaring trammel terhadap hasil tangkapan ikan demersal telah dilakukan di Perairan Indramayu, Jawa Barat pada bulan Juli-November 1995 dengan 46 stasiun penangkapan. Sebanyak enam tipe jaring trammel yang dibuat dengan ukuran benang dan mata jaring berbeda, dioperasikan dalam waktu yang bersamaan. Hasil analisis statistik menunjukkan bahwa hasil tangkapan ikan berbeda nyata jika dilihat dari jumlah ikan yang tertangkap $(p<0,05)$, tetapi tidak berbeda nyata jika dilihat dari bobot ikan $(p>0,05)$. Hasil tangkapan lebih nyata dipengaruhi oleh perbedaan ukuran mata jaring dibanding ukuran benang. Dari 44 jenis ikan dan nonikan yang tertangkap oleh jaring trammel hasil tangkapan dominan adalah ikan gulamah (Johnius spp.) 19,79\%, ikan sebelah (Psettodes erumei) $11,11 \%$, ikan kembung (Rastrelliger spp.) 10,43\%, ikan lidalı (Cynoglossus spp.) 6,92\%, petek (Leiognathus spp.) 6,73\%, dan ikan beloso (Saurida spp.) 5,75\%. Berdasarkan ukuran mata jaring, jenis ikan gulamah dan petek mempunyai perbedaan modus panjang yang jelas, sedang bagi ikan sebelah, ikan lidah, dan beloso tidak terjadi perbedaan yang nyata.
\end{abstract}

\begin{abstract}
Effect of twine diameters and mesh size of trammel net on the catch of demersal fish. By: Wudianto and Heri Harifin.

A study on the effect of twine diameters and mesh size of trammel net on the catch of demersal fish was conducted in Indramayu waters, West Java during the periode of July to September with 46 fishing stations. Six types of trammel nets using different twine diameters and mesh sizes were simultaneously operated. Result of statistical analysis showed that the catch was significantly different in terms of number $(p<0.05)$, but insignificantly different in terms of weight $(p>0.05)$. Catch of trammel nets were more affected by mesh size of net than by diameter of twines. A total of 44 species group of fish and non fish were caught by the trammel nets. The dominant species were croakers (Johnius spp.) 19,79\%, Indian halibut (Psettodes erumei) 11,11\%, Indian meckerel (Rastrelliger sp.) 10,43\%, tonguesole (Cynoglossus spp.) 6,92\%, ponyfish (Leiognathus spp.) 6,73\%, and lizardfish (Saurida spp.) 5,75\%. Based on the mesh size of net, the length modus of croakers and ponyfish were obviously different, but those of Indian halibut, tonguesole and lizardfish were insignificantly different.
\end{abstract}

KEYWORDS: diameter twine, mesh size, trammel net, demersal fish.

\section{PENDAHULUAN}

Setelah 18 tahun dilarangnya pengoperasian pukat trawl sesuai dengan Keppres No.39 Tahun 1980, maka potensi sumber daya ikan demersal di sebagian perairan Indonesia diperkirakan telah pulih kembali. Hasil perhitungan terbaru potensi sumber daya ikan demersal di perairan Indonesia diduga mencapai 1,771 juta ton per tahun dengan tingkat pemanfaatan $47,1 \%$ (Badrudin et al., 1998). Dengan tingkat pemanfaatan sebesar ini masih terdapat peluang untuk meningkatkan pemanfaatannya sehingga dicapai tingkat pengusahaan yang optimum.

Dalam rangka peningkatan pemanfaatan sumber daya perikanan demersal, jaring trammel dengan ukuran benang dan mata jaring lebih besar dapat digunakan sebagai alat tangkap alternatif. Jaring trammel masih dapat digolongkan ke dalam jaring insang dasar di mana pengoperasiannya juga dilakukan di dasar perairan sehingga mampu menangkap jenis-jenis ikan dasar.

Di Indonesia jaring trammel umumnya digunakan untuk menangkap udang penaeid sehingga sebagian nelayan menamakannya sebagai jaring udang. Memang dalam kenyataannya alat tangkap ini juga dapat menangkap ikan demersal, yang dianggap merupakan hasil tangkapan sampingan (by catch) (Monintja \& Sondita, 1996). Bahan yang digunakan untuk jaring trammel saat ini adalah benang yang berukuran kecil yaitu jaring lapis luar PA 210 d/6 dan jaring lapis dalam PA $210 \mathrm{~d} / 2$ atau PA

"Peneliti pada Balai Penelitian Perikanan Laut 
monofilament sehingga mudah mengalami kerusakan (Wudianto et al., 1988). Di Jepang, jaring trammel dengan menggunakan ukuran benang dan mata jaring yang lebih besar ternyata sangat produktif digunakan untuk menangkap ikan demersal berukuran besar, seperti jenis ikan Branchiostegus japonicus (Matsuda \& Kitahara, 1967).

Berdasarkan hasil penelitian, efektivitas jaring trammel untuk menangkap ikan atau udang sangat dipengaruhi oleh ukuran mata jaring lapis dalam (inner net) karena berkaitan dengan selektivitasnya (Kitahara, 1968; Koike \& Takeuchi, trammel yang efektif untuk menangkap ikan demersal dengan ukuran tertentu.

\section{BAHAN DAN METODE}

Uji coba penangkapan dengan jaring trammel dilakukan di Perairan Utara Jawa, tepatnya di Perairan Indramayu dan sekitarnya (Gambar 1). Penelitian ini dilakukan sebanyak tiga kali trip yaitu pada bulan Juli, September, dan November 1995 dengan menggunakan perahu motor berukuran 8 GT yang dilengkapi motor tempel berkekuatan 19 PK. Enam tipe jaring trammel dengan konstruksi yang berlainan, baik ukuran

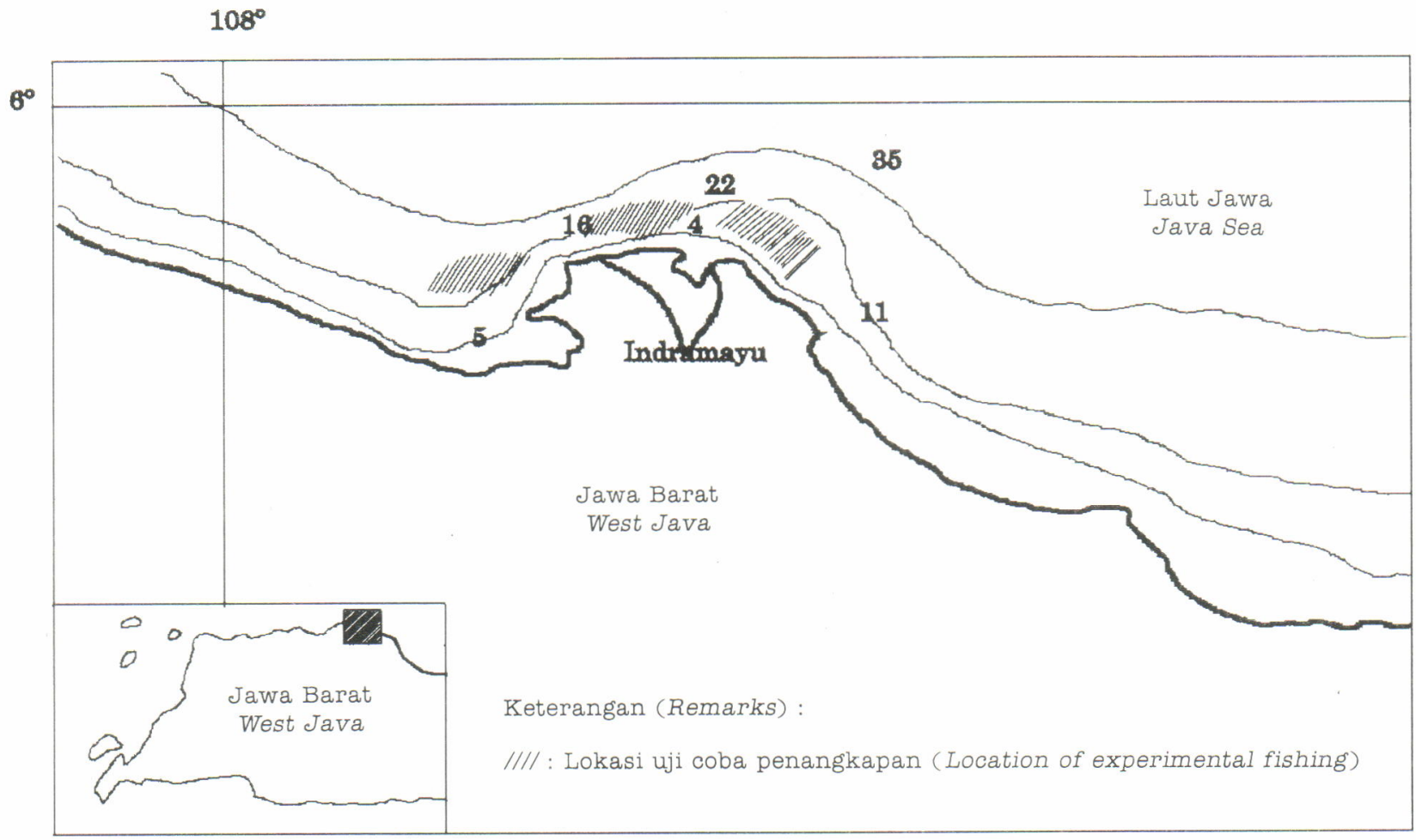

Gambar 1. Peta Perairan Indramayu menunjukkan lokasi uji coba jaring trammel.

Figure 1. Map of Indramayu waters showing location of experimental fishing for trammel net.

1985; Monintja \& Sondita, 1996). Di samping lebar mata jaring, ukuran/diameter benang juga merupakan faktor penting yang menentukan keberhasilan penangkapan ikan karena berkaitan dengan elastisitas jaring.

Dalam penelitian ini telah diuji coba beberapa tipe jaring trammel yang dibuat dengan ukuran benang dan mata jaring yang berbeda. Dengan adanya penelitian ini diharapkan dapat diketahui pengaruh ukuran benang dan mata jaring terhadap hasil tangkapan ikan demersal, baik terhadap jumlah ikan maupun ukuran ikan yang tertangkap sehingga dapat diperoleh tipe jaring benang maupun lebar mata jaringnya (Gambar 2) telah diujicobakan. Spesifikasi masing-masing tipe jaring dijelaskan pada Tabel 1.

Keenam tipe jaring ini menggunakan bahan jaring lapis luar yang sama yaitu nilon $210 \mathrm{~d} / 24$, dengan ukuran mata jaring yang berbeda yaitu 8 inci, 10 inci, dan 12 inci. Penentuan ukuran mata jaring lapis luar disesuaikan dengan ukuran mata jaring lapis dalam dengan perbandingan $4: 1$. Pemakaian perbandingan ini mengikuti pedoman pada jaring trammel yang telah berkembang saat ini. Koefisien pengikatan jaring (hanging ratio) untuk keenam tipe jaring dibuat sama yaitu 0,65 

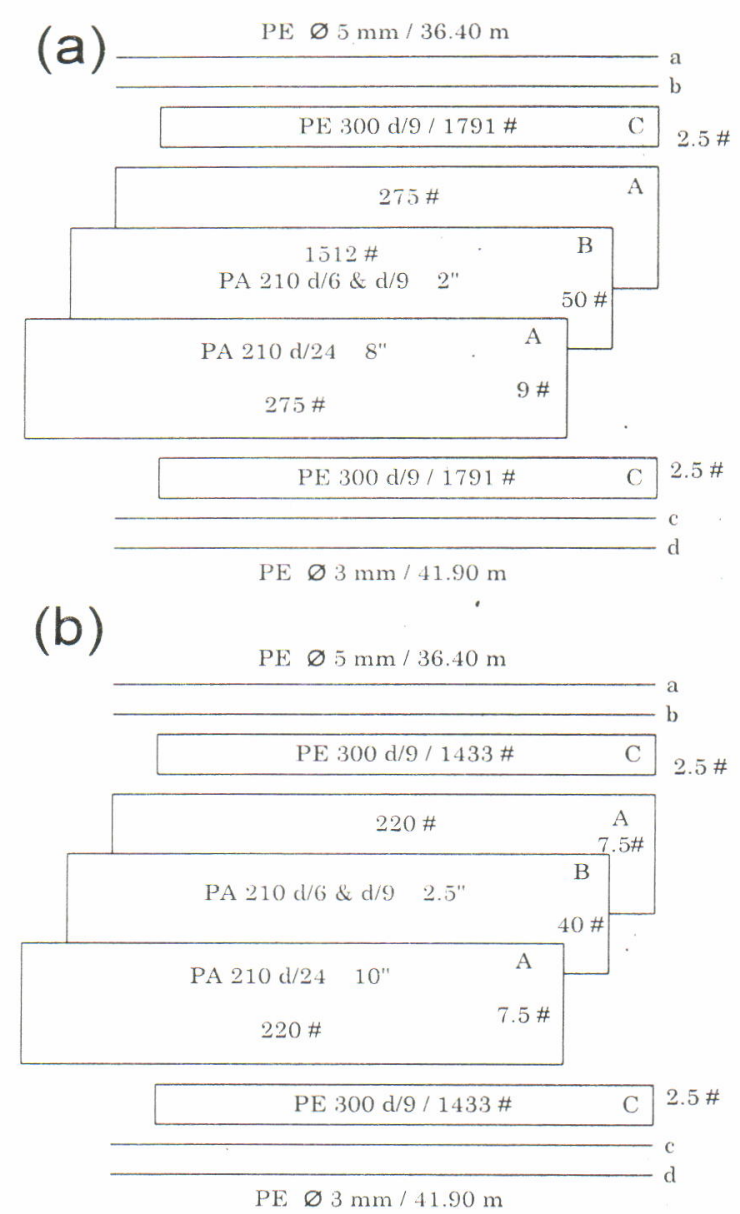

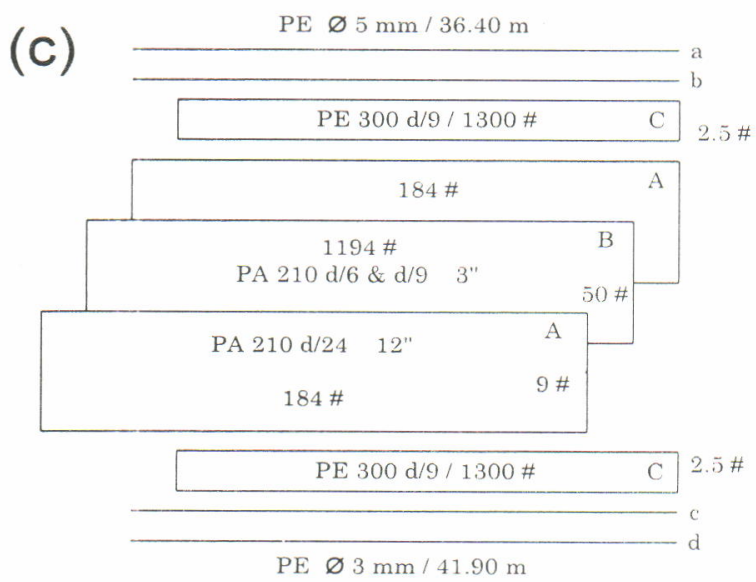

Keterangan (Remarks):

A. jaring lapis luar (outer net)

B. jaring lepas dalam (inner net

C. serampat (selvedge)

a. tali pelampung (float line

b. tali ris atas (head line)

c. tali ris bawah (footrope)

d. tali pemberat (sinker line)

Gambar 2.Rancang bangun jaring trammel: (a) tipe I dengan ukuran mata 2"; (b) tipe II ukuran mata 2,5"; (c) tipe III dengan ukuran mata 3".

Figure 2. Design of trammel net: (a) type I using 2" mesh size; (b) type II using 2,5" mesh size; (c) type III using 3" mesh size.

pada jaring lapis luar dan 0,40 pada jaring lapis dalam sehingga tinggi jaring mencapai $1,40 \mathrm{~m}$. Demikian juga dengan panjang jaring setelah diikat pada tali ris semuanya sama yaitu sebesar $36,40 \mathrm{~m}$ untuk tali ris atas dan $41,90 \mathrm{~m}$ untuk tali ris bawah. Bahan yang digunakan untuk tali ris adalah PE (polyethylene) berdiameter 3 dan $5 \mathrm{~mm}$. Dengan kontruksi yang demikian ini maka parameter yang dijadikan perlakuan adalah bahan jaring lapis dalam yaitu ukuran benang dan mata jaring.

Penangkapan dengan keenam tipe jaring trammel telah dilakukan pada 46 stasiun penangkapan dengan rincian: 18 stasiun pada trip bulan Juli, 16 stasiun pada trip bulan September, dan 12 stasiun pada trip bulan November 199.5. Dalam uji coba di lapangan, keseluruhan tipe jaring dioperasikan secara bersamaan dengan metode pengoperasian dipasang menetap di dasar perairan.
Jaring disusun secara acak sehingga akan mengurangi bias data hasil tangkapan yang dikumpulkan. Jaring dioperasikan pada siang dan malam hari dengan lama pengoperasian antara 2-3 jam. Waktu penangkapan bukan merupakan parameter penting dalam penelitian ini karena keseluruhan jaring dioperasikan secara bersamaan. Kedalaman perairan daerah penangkapan berkisar antara 3 $40 \mathrm{~m}$. Semua tipe jaring mendapat perlakuan yang sama terhadap masing-masing kedalaman sehingga pengaruh kedalaman terhadap hasil tangkapan tidak dibahas. Hasil tangkapan yang diperoleh pada setiap stasiun penangkapan dipisahkan berdasarkan tipe jaring, kemudian diidentifikasi berdasarkan spesiesnya (Gloerfelt-Trap \& Kailola, 1985). Semua jenis ikan yang tertangkap dihitung jumlahnya dan ditimbang bobotnya dalam satuan gram.

Untuk mengetahui pengaruh ukuran benang dan mata jaring terhadap hasil tangkapan 
Tabel 1. Spesifikasi jaring trammel yang diujicobakan.

Table 1. Specification of trammel net for experimental fishing.

\begin{tabular}{|c|c|c|c|c|}
\hline \multirow{3}{*}{$\begin{array}{l}\text { Tipe jaring } \\
\text { Type of } \\
\text { trammel net }\end{array}$} & \multicolumn{4}{|c|}{ Spesifikasi jaring (Specification of net) } \\
\hline & \multicolumn{2}{|c|}{$\begin{array}{c}\text { Jaring lapis luar } \\
\text { Outer net }\end{array}$} & \multicolumn{2}{|c|}{$\begin{array}{c}\text { Jaring lapis dalam } \\
\text { Inner net }\end{array}$} \\
\hline & $\begin{array}{l}\text { Ukuran benang } \\
\text { Diameter of } t \text { wine }\end{array}$ & $\begin{array}{c}\text { Ukuran mata } \\
\text { Mesh size }\end{array}$ & $\begin{array}{l}\text { Ukuran benang } \\
\text { Diameter of twine }\end{array}$ & $\begin{array}{c}\text { Ukuran mata } \\
\text { Mesh size }\end{array}$ \\
\hline Tipe IA & Nylon $210 \mathrm{~d} / 24$ & $8^{\prime \prime}$ & Nylon $210 \mathrm{~d} / 6$ & $2.0^{\prime \prime}$ \\
\hline IB & Nylon $210 \mathrm{~d} / 24$ & $8^{\prime \prime}$ & Nylon $210 \mathrm{~d} / 9$ & $2.0^{\prime \prime}$ \\
\hline Tipe IIA & Nylon $210 \mathrm{~d} / 24$ & $10^{\prime \prime}$ & Nylon $210 \mathrm{~d} / 6$ & $2.5^{\prime \prime}$ \\
\hline IIB & Nylon 210 d/24 & $10^{\prime \prime}$ & Nylon $210 \mathrm{~d} / 9$ & $2.5^{\prime \prime}$ \\
\hline Tipe IIIA & Nylon 210 d/24 & $12^{\prime \prime}$ & Nylon $210 \mathrm{~d} / 6$ & $3.0^{\prime \prime}$ \\
\hline IIIB & Nylon $210 \mathrm{~d} / 24$ & $12^{\prime \prime}$ & Nylon $210 \mathrm{~d} / 9$ & $3.0^{\prime \prime}$ \\
\hline
\end{tabular}

digunakan uji perbedaan beberapa nilai tengah melalui analisis ragam (analysis of variance, ANOVA), baik terhadap jumlah ikan yang tertangkap (ekor) ataupun bobot ikan (gram) (Zar, 1984). Apabila hasil uji ANOVA menunjukkan perbedaan yang nyata $(\mathrm{p}<0,05)$, maka pengujian dilanjutkan dengan uji beda nyata terkecil (BNT) untuk mengetahui perlakuan mana yang mempunyai perbedaan nyata $(\mathrm{p}<0,05)$.

Jenis ikan demersal yang dominan tertangkap diukur panjangnya dalam satuan centimeter. Untuk memudahkan membandingkan ukuran ikan yang tertangkap pada masing-masing ukuran mata jaring dihitung modus panjang ikan dengan rumus sebagai berikut:

$$
\mathrm{Mo}=\mathrm{L}+\mathrm{p}\left(\frac{\mathrm{L} 1}{\mathrm{~L} 1+\mathrm{L} 2}\right)
$$

di mana:

$\mathrm{L}$ = batas bawah kelas modal (kelas interval panjang ikan dengan frekuensi terbanyak)

$\mathrm{p}=$ panjang kelas

L1= frekuensi kelas modal dikurangi frekuensi kelas interval terdekat sebelumnya

L2= frekuensi kelas modal dikurangi frekuensi kelas interval terdekat berikutnya

\section{HASIL DAN BAHASAN}

Selama uji coba di laut hasil tangkapan yang diperoleh dari keenam tipe jaring cukup bervariasi berkisar antara 0 sampai 45 ekor/ tinting/stasiun. Rata-rata hasil tangkapan bagi masing-masing tipe jaring, baik berdasarkan jumlah atau bobot disajikan pada Tabel 2 .

Rata-rata hasil tangkapan ikan berdasarkan bobot tidak berfluktuasi nyata, yaitu berkisar antara 451-690 g/tinting/stasiun, sedang berdasarkan jumlah ikan sangat bervariasi berkisar antara 2-6 ekor/tinting/stasiun. Hasil analisis ragam (ANOVA) terhadap hasil tangkapan dari keenam tipe jaring disajikan pada Tabel 3 .

Dari Tabel 3 terlihat bahwa terjadi berbedaan yang sangat nyata ( $p=0.01$ ) terhadap jumlah ikan (ekor) yang tertangkap oleh masing-masing tipe jaring, namun berdasarkan bobot ikan yang tertangkap hasilnya tidak berbeda nyata $(p=0,77)$. Adanya perbedaan yang nyata terhadap jumlah hasil tangkapan dan tidak terjadi perbedaan yang nyata terhadap bobot ikan yang tertangkap menunjukkan bahwa kaidah selektivitas berlaku untuk jaring trammel yang dioperasikan. Hasil yang sama juga diperoleh dari penelitian jaring trammel untuk penangkapan udang di Perairan Pelabuhan Ratu, yaitu dengan menggunakan berbagai ukuran mata jaring lapis dalam ternyata bobot udang hasil tangkapan tidak berbeda nyata, sedang jumlah udang (ekor) sangat berbeda (Monintja \& Sondita, 1996).

Hasil uji beda nyata terkecil (BNT) menunjukkan bahwa hasil tangkapan yang diperoleh masing-masing tipe jaring tidak seluruhnya berbeda nyata. Tipe jaring yang dibuat dari ukuran/diameter benang berlainan, dengan ukuran mata jaring sama (IA vs IB, IIA vs IIB, IIIA vs IIIB) ternyata mengasilkan hasil tangkapan yang tidak berbeda nyata (Tabel 4). 
Tabel 2. Hasil tangkapan ikan berdasarkan tipe jaring trammel.

Table 2. Catch of fish caught by type of trammel net.

\begin{tabular}{|c|c|c|c|c|c|c|}
\hline \multirow{2}{*}{$\begin{array}{c}\text { Hasil Tangkapan } \\
\text { Catch }\end{array}$} & \multicolumn{6}{|c|}{ Tipe Jaring (Type of net) } \\
\hline & IA & IB & IIA & IIB & IIIA & IIIB \\
\hline $\begin{array}{l}\text { Jumlah stasiun } \\
\text { Number of station }\end{array}$ & 46 & 46 & 46 & 46 & 46 & 46 \\
\hline $\begin{array}{l}\text { Bobot hasil tangkapan }(\mathrm{kg}) \\
\text { Catch in weight }(\mathrm{kg})\end{array}$ & 31.770 & 29.245 & 24.410 & 26.350 & 30.900 & 20.740 \\
\hline $\begin{array}{l}\text { Rata-rata hasil tangkapan/stasiun }(\mathrm{g}) \\
\text { Average of catch/station (g) }\end{array}$ & 690 & 636 & 530 & 572 & 672 & 451 \\
\hline $\begin{array}{l}\text { Jumlah hasil tangkapan (ekor) } \\
\text { Catch in number (fish) }\end{array}$ & 256 & 233 & 157 & 160 & 130 & 90 \\
\hline $\begin{array}{l}\text { Rata-rata hasil tangkapan/stasiun (ekor) } \\
\text { Average of catch/station (fish) }\end{array}$ & 5.56 & 5.06 & 3.41 & 3.47 & 2.82 & 1.96 \\
\hline $\begin{array}{l}\text { Rata-rata bobot ikan/ekor (g) } \\
\text { Average of weight/fish (g) }\end{array}$ & 124.1 & 125.5 & 155.5 & 164.7 & 237.7 & 231.0 \\
\hline
\end{tabular}

Tabel 3. Analisis ragam terhadap hasil tangkapan berdasarkan tipe jaring.

Table 3. Analysis of variance (ANOVA) for catch by type of trammel net.

\begin{tabular}{|c|c|c|c|c|c|c|c|c|c|}
\hline \multirow{2}{*}{$\begin{array}{l}\text { Sumber } \\
\text { Source }\end{array}$} & \multirow{2}{*}{$\begin{array}{l}\mathrm{Db} \\
D f\end{array}$} & \multicolumn{4}{|c|}{$\begin{array}{c}\text { Jumlah ikan (Number of } \\
\text { fish) }\end{array}$} & \multicolumn{4}{|c|}{ Bobot ikan (Weight of fish) } \\
\hline & & SS & MS & $\mathbf{F}$ & $\mathbf{P}$ & SS & MS & $\mathrm{F}$ & $\mathbf{P}$ \\
\hline $\begin{array}{l}\text { Antar kelompok } \\
\text { Between group }\end{array}$ & 5 & 426.69 & 85.34 & 3.13 & $0.01^{* * *}$ & $1.9 \times 10^{6}$ & $3.8 \times 10^{5}$ & 0.51 & $0.77^{\mathrm{ns}}$ \\
\hline $\begin{array}{l}\text { Dalam kelompok } \\
\text { Within group }\end{array}$ & 270 & 7353.26 & 27.23 & & & $203 \times 10^{6}$ & $7.5 \times 10^{5}$ & & \\
\hline Total & 275 & 7779.96 & & & & $205 \times 10^{6}$ & & & \\
\hline
\end{tabular}

Dengan perbedaan ukuran benang antara PA $210 \mathrm{~d} / 6$ dan PA $210 \mathrm{~d} / 9$ ternyata kurang berpengaruh terhadap elastisitas jaring. Padahal menurut Klaust (1982), jaring yang terbuat dari benang berdiameter kecil seperti PA $210 \mathrm{~d} / 6$ biasanya mempunyai daya lentur (elastisitas) lebih tinggi dibanding jaring yang terbuat dari benang yang berdiameter lebih besar. Daya lentur yang tinggi pada jaring semestinya mampu meningkatkan efektivitas penangkapan, namun sebaliknya mempunyai kelemahan di mana jaring cepat rusak. Jaring yang terbuat dari benang berukuran besar (PA 210 d/9) umumnya lebih kuat sehingga tidak mudah rusak dan tahan lama.

Jaring trammel yang dibuat dengan ukuran mata jaring dengan perbedaan 0,5 inci ternyata memperoleh hasil tangkapan yang tidak berbeda nyata, namun bagi jaring dengan perbedaan mata 1,0 inci menunjukkan perbedaan yang nyata (IA, IB vs IIIA, IIIB). Dari hasil ini dapat dikatakan jaring trammel yang mempunyai ukuran mata kecil (IA dan IB) mampu menangkap ikan lebih banyak dibanding jaring yang mempunyai ukuran mata lebih besar (IIIA dan IIIB) (Tabel 2). Tipe jaring yang mempunyai ukuran mata kecil umumnya ikan yang tertangkap berukuran lebih kecil dibanding ikan yang tertangkap oleh tipe jaring yang berukuran mata lebih besar. Ini terlihat jelas pada Tabel 2 yaitu rata-rata bobot per ekor ikan yang tertangkap tipe jaring IA dan IB sebesar $124,1 \mathrm{~g}$ dan $125,5 \mathrm{~g}$, sedang bagi tipe jaring IIA, IIB, IIIA, dan IIIB bobotnya berturutturut sebesar 155,5, 164,7, 237,7 dan 231,0 g. Jika dilihat dari segi pengelolaan sumber daya 
Tabel 4. Hasil uji BNT terhadap hasil tangkapan jaring trammel. Table 4. Result of LSD-test for the catch of trammel net.

\begin{tabular}{|c|c|c|c|c|c|c|}
\hline $\begin{array}{l}\text { Tipe jaring } \\
\text { Type of net }\end{array}$ & IA & IB & IIA & IIB & IIIA & IIIB \\
\hline IA & & $0.53^{1 \mathrm{ss}}$ & $1: 96^{1 \mathrm{ls}}$ & $1.85^{\mathrm{ns}}$ & $2.57^{*}$ & $3.46^{*}$ \\
\hline IB & & & $2.52^{1 \mathrm{ss}}$ & $2.40^{1 \mathrm{~ns}}$ & $3.12^{*}$ & 4.03 * \\
\hline IIA & & & & $0.11^{\mathrm{ns}}$ & $0.57^{1 \mathrm{ss}}$ & $1.48^{\mathrm{ns}}$ \\
\hline IIB & & & & & $0.70^{\mathrm{ns}}$ & $1.61^{\mathrm{ns}}$ \\
\hline IIIA & & & & & & $0.89^{\mathrm{ns}}$ \\
\hline IIIB & & & & & & \\
\hline
\end{tabular}

* : berbeda nyata (significantly different) $(p<0.05)$

ns: tidak berbeda nyata (not significantly different) $(p>0.05)$

perikanan, maka tipe jaring IIIA dan IIIB sangat layak dikembangkan karena tipe jaring ini mampu menangkap ikan yang berukuran lebih besar.

Jenis ikan yang tertangkap dengan alat tangkap jaring trammel selama uji coba penangkapan adalah sebanyak 44 kelompok spesies. Setiap tipe jaring mempunyai kemampuan berbeda untuk menangkap berbagai jenis ikan. Jaring tipe IA mampu menangkap 33 jenis ikan, IB sebanyak 29 jenis, IIA sebanyak 27 jenis, IIB sebanyak 23 jenis, IIIA sebanyak 26 jenis, dan IIIB sebanyak 22 jenis. Jaring yang terbuat dari benang berukuran kecil baik diameter benang ataupun ukuran mata jaring terlihat kurang selektif dalam menangkap ikan dan ini terbukti dengan banyaknya jenis ikan yang tertangkap. Secara keseluruhan jenis ikan yang dominan tertangkap adalah gulamah (Johnius spp.) 19,79\%, sebelah (Psettodes erumei) 11,11\%, kembung (Rastrelliger spp.) 10,43\%, ikan lidah (Cynoglossus spp.) 6,92\%, petek (Leiognathus spp.) $673 \%$, dan beloso (Saurida spp.) 5,75\% (Tabel 5).

Jenis ikan gulamah dan ikan sebelah merupakan hasil tangkapan yang dominan untuk setiap tipe jaring, sedangkan ikan lidah, petek, dan beloso lebih banyak tertangkap pada jaring yang mempunyai ukuran mata kecil yaitu 2 inci (tipe IA dan IB) dan 2,5 inci (tipe IIA dan IIB). Kejadian ini berkaitan erat dengan variasi ukuran ikan yang tertangkap di mana jenis ikan gulamah dan ikan sebelah mempunyai ukuran mulai dari yang kecil sampai besar, sedang jenis ikan lidah, petek, dan beloso sebagian besar berukuran kecil. Dengan jaring trammel ternyata dapat tertangkap juga jenis ikan pelagis seperti kembung, padahal jaring dioperasikan di dasar perairan. Tertangkapnya ikan pelagis ini diduga karena alat tangkap dioperasikan pada perairan yang relatif dangkal dengan kedalaman sekitar $10 \mathrm{~m}$. Ikan kembung dapat juga tertangkap pada saat penarikan jaring trammel ke atas kapal. Meskipun secara persentase ikan kembung tertangkap cukup banyak, namun dalam frekuensi kejadian sangat kecil karena hanya terdapat pada tiga stasiun penangkapan. Sebagian besar ikan kembung tertangkap pada jaring trammel berukuran mata 2 inci (Tabel 5) sehingga ukuran ikan yang tertangkap relatif kecil dengan modus panjang sekitar $20 \mathrm{~cm}$.

Hasil pengukuran terhadap jenis ikan yang dominan tertangkap menunjukkan bahwa tidak terdapat perbedaan nyata terhadap ukuran ikan yang tertangkap oleh jaring yang dibuat dengan ukuran benang berbeda. Sebaliknya dengan ukuran mata jaring berbeda memberikan perbedaan ukuran ikan yang tertangkap. Jenis ikan yang diukur panjangnya yaitu ikan gulamah, ikan sebelah, beloso, lidah dan petek. Bentuk badan ikan ternyata sangat berpengaruh terhadap selektivitas jaring dalam menjerat ikan. Hal ini terlihat dari hasil pengukuran terhadap ikan gulamah dan petek, yaitu bahwa besarnya ukuran ikan yang tertangkap mengikuti besarnya ukuran jaring. Kejadian ini sesuai dengan kaidah selektivitas jaring di mana jaring yang mempunyai ukuran mata besar akan lebih selektif dibanding jaring yang mempunyai ukuran mata kecil. Jenis ikan lainnya seperti ikan sebelah, ikan lidah dan beloso yang bentuknya pipih dan silinder tampaknya tidak mengikuti kaidah selektivitas jaring, karena banyak ikan berukuran besar tertangkap oleh jaring berukuran mata kecil. Adanya perbedaan ukuran dari masing-masing jenis ikan yang tertangkap oleh ukuran mata jaring yang berbeda terlihat jelas pada Tabel 6 . 
Tabel 5. Komposisi jenis ikan yang tertangkap berdasarkan ukuran mata jaring trammel.

Table 5. Species composition of fish caught by different mesh sizes of trammel net.

\begin{tabular}{|c|c|c|c|c|c|c|c|c|}
\hline \multirow{2}{*}{$\begin{array}{c}\text { Jenis Ikan } \\
\text { Species }\end{array}$} & \multicolumn{2}{|c|}{ 2" $(2$ inch $)$} & \multicolumn{2}{|c|}{$2,5^{\prime \prime}(2.5$ inch $)$} & \multicolumn{2}{|c|}{$3 "(3$ inch $)$} & \multicolumn{2}{|c|}{ Total } \\
\hline & $\begin{array}{l}\text { ekor } \\
\text { ind. }\end{array}$ & $\%$ & $\begin{array}{l}\text { ekor } \\
\text { ind. }\end{array}$ & $\%$ & $\begin{array}{l}\text { ekor } \\
\text { ind. }\end{array}$ & $\%$ & $\begin{array}{l}\text { ekor } \\
\text { ind. }\end{array}$ & $\%$ \\
\hline Gulamah (Johnius spp.) & 73 & 14.93 & 83 & 26.18 & 47 & 21.36 & 203 & 19.79 \\
\hline Sebelah (Psettodes erumei) & 49 & 10.02 & 40 & 12.62 & 25 & 11.36 & 114 & 11.11 \\
\hline Kembung (Rastrelliger spp.) & 87 & 17.79 & 13 & 4.10 & 7 & 3.18 & 107 & 10.43 \\
\hline Lidah (Cynoglossus spp.) & 34 & 6.95 & 28 & 8.83 & 9 & 4.09 & 71 & 6.92 \\
\hline Pari (Dasyatis spp.) & 14 & 2.86 & 23 & 7.26 & 34 & 14.45 & 71 & 6.92 \\
\hline Petek (Leiognathus spp.) & 41 & 8.38 & 24 & 7.57 & 4 & 1.82 & 69 & 6.73 \\
\hline Beloso (Saurida spp.) & 40 & 8.18 & 13 & 4.10 & 6 & 2.73 & 59 & 5.75 \\
\hline Rajungan (Portunus pelagicus) & 17 & 3.48 & 15 & 4.73 & 16 & 7.27 & 48 & 4.68 \\
\hline Sotong (Sepia sp.) & 20 & 4.09 & 6 & 1.89 & 5 & 2.27 & 31 & 3.02 \\
\hline Manyung (Osteogenesius spp.) & 13 & 2.66 & 5 & 1.58 & 8 & 3.64 & 26 & 2.53 \\
\hline Kakap (Lates sp.) & 13 & 2.66 & 9 & 2.84 & 3 & 1.36 & 25 & 2.44 \\
\hline Gero-gerot (Pomadasys hasta) & 9 & 1.84 & 10 & 3.15 & 7 & 3.18 & 26 & 2.53 \\
\hline Udang jerbung (Penaeus spp.) & 11 & 2.25 & 6 & 1.89 & 4 & 1.82 & 21 & 2.05 \\
\hline Baji-baji (Platisepatidae) & 4 & 0.82 & 6 & 1.89 & 6 & 2.73 & 16 & 1.56 \\
\hline Bronang (Siganus spp.) & 3 & 0.61 & 3 & 0.95 & 8 & 3.64 & 14 & 1.36 \\
\hline Tigawaja (Pseudosciaena spp.) & 9 & 1.84 & 2 & 0.63 & 1 & 0.45 & 13 & 1.17 \\
\hline Buntal (Diodon spp.) & 1 & 0.20 & 6 & 1.89 & 4 & 1.82 & 11 & 1.07 \\
\hline Kurisi (Nemipterus spp.) & 6 & 1.23 & 3 & 0.95 & 1 & 0.45 & 10 & 0.97 \\
\hline Kerong-kerong (Therapon spp.) & 8 & 1.64 & 2 & 0.63 & 0 & 0.00 & 10 & 0.97 \\
\hline Kerapu (Epinephelus spp.) & 3 & 0.61 & 2 & 0.63 & 2 & 0.91 & 7 & 0.68 \\
\hline Scarus spp. & 2 & 0.41 & 2 & 0.63 & 3 & 1.36 & 7 & 0.68 \\
\hline Thalossoma spp. & 1 & 0.20 & 1 & 0.32 & 5 & 2.27 & 7 & 0.68 \\
\hline Kuro (Polynemus spp.) & 4 & 0.82 & 1 & 0.32 & 1 & 0.45 & 6 & 0.58 \\
\hline Remang (Congresox talapon) & 2 & 0.41 & 3 & 0.95 & 1 & 0.45 & 6 & 0.58 \\
\hline Slanget (Anadontostoma spp.) & 4 & 0.82 & 1 & 0.32 & 1 & 0.45 & 6 & 0.58 \\
\hline Layur (Trichiurus spp.) & 5 & 1.02 & 0 & 0.00 & 0 & 0.00 & 5 & 0.49 \\
\hline Platycephalus spp. & 2 & 0.41 & 0 & 0.00 & 3 & 1.36 & 5 & 0.49 \\
\hline Tanda-tanda (Lutjanus vitta) & 3 & 0.61 & 0 & 0.00 & 0 & 0.00 & 3 & 0.29 \\
\hline Geres (Gerres spp.) & 2 & 0.41 & 1 & 0.32 & 0 & 0.00 & 3 & 0.29 \\
\hline Cucut (Carcharinus spp.) & 0 & 0.00 & 3 & 0.95 & 0 & 0.00 & 3 & 0.29 \\
\hline Kanang (Seriolina spp.) & 0 & 0.00 & 2 & 0.63 & 1 & 0.45 & 3 & 0.29 \\
\hline Alu-alu (Sphyraena spp.) & 1 & 0.20 & 0 & 0.00 & 1 & 0.45 & 2 & 0.19 \\
\hline Selar (Selaroides spp.) & 1 & 0.20 & 1 & 0.32 & 0 & 0.00 & 2 & 0.19 \\
\hline Lencam (Lethrinus lencam) & 2 & 0.41 & 0 & 0.00 & 0 & 0.00 & 2 & 0.19 \\
\hline Mata besar (Priacanthus spp.) & 1 & 0.20 & 0 & 0.00 & 0 & 0.00 & 1 & 0.10 \\
\hline Lepu (Scorpaenidae) & 1 & 0.20 & 0 & 0.00 & 0 & 0.00 & 1 & 0.10 \\
\hline Putihan (Lactarius lactarius) & 1 & 0.20 & 0 & 0.00 & 0 & 0.00 & 1 & 0.10 \\
\hline Kuniran (Upeneus spp.) & 1 & 0.20 & 0 & 0.00 & 0 & 0.00 & 1 . & 0.10 \\
\hline Gebel (Platax spp.) & 0 & 0.00 & 1 & 0.32 & 0 & 0.00 & 1 & 0.10 \\
\hline Daun bambu (Chorinemus tol) & 0 & 0.00 & 0 & 0.00 & 1 & 0.45 & 1 & 0.10 \\
\hline Tetengkek (Megalaspis cordyla) & 0 & 0.00 & 0 & 0.00 & 1 & 0.45 & 1 & 0.10 \\
\hline Ephipus spp. & 0 & 0.00 & 0 & 0.00 & 1 & 0.45 & 1 & 0.10 \\
\hline Bilis (Ilisha spp.) & 0 & 0.00 & 0 & 0.00 & 1 & 0.45 & 1 & 0.10 \\
\hline Ikan lainnya (Other fish) & 1 & 0.20 & 0 & 0.00 & 4 & 1.82 & 5 & 0.49 \\
\hline Total & 489 & 100.00 & 317 & 100.00 & 220 & 100.00 & 1,026 & 100.00 \\
\hline
\end{tabular}


Tabel 6. Ukuran panjang total ikan yang dominan tertangkap berdasarkan ukuran mata jaring trammel.

Table 6. Total length of fish dominantly caught by different mesh size of trammel net.

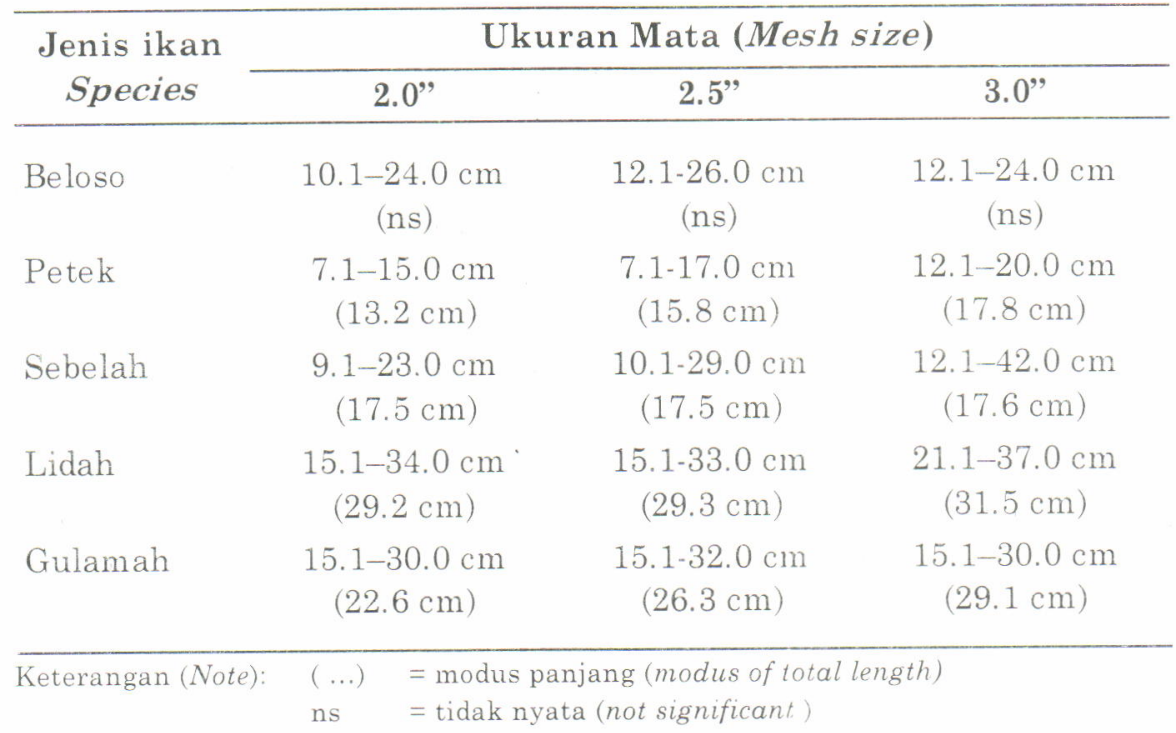

Karena ikan beloso mempunyai bentuk badan silinder sehingga banyak ikan yang berukuran besar tertangkap juga dengan jaring yang berukuran mata kecil, maka dengan kondisi yang demikian sulit ditemui modus panjang ikan beloso berdasarkan ukuran mata jaring karena berbagai ukuran ikan hampir merata tertangkap oleh masing-masing ukuran mata jaring. Ikan sebelah mempunyai modus panjang yang sama antar ukuran mata jaring yaitu 17,5 cm, demikian juga dengan ikan lidah tidak terlihat ada perbedaan yang nyata antar ukuran mata jaring. Sedang modus panjang ikan petek terlihat cukup jelas perbedaannya antara ukuran mata jaring 2 inci, 2,5 inci, dan 3 inci yaitu masing-masing sebesar $13,2 \mathrm{~cm}, 15,8 \mathrm{~cm}$, dan $17,8 \mathrm{~cm}$. Hal yang sama juga terjadi pada ikan gulamah, di mana modus panjangnya terlihat semakin besar sesuai dengan ukuran mata jaringnya, yaitu $22,6 \mathrm{~cm}$ bagi mata jaring 2 inci, $26,3 \mathrm{~cm}$ bagi mata jaring 2,5 inci; 29,1 cm bagi mata jaring 3 inci. Oleh sebab itu dalam menentukan selektivitas alat tangkap, bentuk badan dari ikan yang menjadi tujuan penangkapan sangat berpengaruh. Di samping itu cara tertangkapnya ikan juga merupakan faktor penting, terutama bagi jenis alat tangkap yang tergolong ke dalam klasifikasi jaring insang atau gillnet.

\section{KESIMPULAN DAN SARAN}

1. Hasil tangkapan jaring trammel tidak berbeda nyata jika dilihat dari bobot ikan dan berbeda nyata jika dilihat dari jumlah ikan yang tertangkap. Besarnya ukuran benang (210 d/6 dan $210 \mathrm{~d} / 9$ ) ternyata tidak mempunyai pengaruh terhadap hasil tangkapan sehingga adanya perbedaan hasil tangkapan lebih disebabkan oleh variasi ukuran mata jaring.

2.Dari 44 jenis ikan yang tertangkap dengan alat tangkap jaring trammel selama uji coba penangkapan, hasil tangkapan dominan adalah ikan gulamah, sebelah, lidah, kembung, beloso, dan petek.

3. Bentuk badan ikan sangat berpengaruh terhadap proses tertangkapnya ikan secara terjerat (gilled) oleh jaring trammel. Perbedaan modus panjang ikan yang tertangkap oleh berbagai ukuran mata jaring terlihat jelas pada ikan gulamah dan petek, sedang pada jenis ikan yang lain perbedaannya tidak nyata.

\section{DAFTAR PUSTAKA}

Badrudin, M., Tampubolon, G.H., Iskandar, B., Raharjo, P. dan Basuki, R. 1998. Sumberdaya ikan demersal. Potensi dan penyebaran sumberdaya ikan laut di perairan Indonesia. (Eds) Widodo, J., Aziz, K.H., Priyono, B.E., Tampubolon, G.H., Naamin, N. dan Djamali, A. Komisi Nasional Pengkajian Stok Sumbar Daya Ikan Laut. LIPI. 139-155.

Gloerfelt-Trap, T. and Kailola, P.J. 1985. Trawled fishes of southern Indonesia and northwestern Australia. The Australian Development Assistance Bureau (ADAB)-The Directorate General of Fisheries Indonesia-The German Agency for Technical Cooperation. Canberra. Australia. 406 pp. 
Kitahara, T. 1968. On sweeping trammel net ( kogisasiami) fishery along cast of the Saa'in District III. Mesh selectivity curve of sweeping trammel net for branquilos. Bulletin of the Japanese Society of Scientific Fisheries., 34 (9): 759-763.

Klaust, G. 1982. Netting Materials for Fishing Gear. Fishing News Books., Farnham Surrey. England. $246 \mathrm{pp}$.

Koike, A. and Takeuchi, S. 1985. Effect of trammel net with different sizes of mesh of inside net on catching efficiency. Bulletin of the Japanese Society of Scientific Fisheries. 51(6):895-901.

Koike, A. and Matuda, K. 1988. Catching efficiency of slacknesses and mesh size of inner net. Nippon Suisan Gakkaishi. 54(2): 221-227.

Matsuda, K. and Kitahara, T. 1967. On the estimation of catching efficiency of sweeping trammel net.
Bulletin of the Japanese Society of Scientific Fisheries. 53(12): 1096-1098.

Monintja, D.R. and Sondita, M.F.A. 1996. Study on selectivity and by-catch of trammel net in Pelabuhan Ratu waters, West Java. Round Table Meeting. Fisheries Research and Development Activities Towards Responsible Fishing. 40: 20-39.

Wudianto, Widodo, A.P.A. dan Nasution, C. 1988. Pengaruh penggunaan benang monofilament dan multifilament sebagai bahan jaring tiga lapis (trammel net) terhadap hasil tangkapan udang jerbung (Penaeus merguiensis). Jurnal Penelitian Perikanan Laut. 48: 83-91.

Zar, J. H. 1984. Biostatistical Analysis. Prentice-Hall. Inc. Englewood Cliffs. New Jersey. 718 pp. 